\title{
Antimicrobial, cytotoxic and antioxidant activity of saponins and tannins extracts of Algerian Glycyrrhiza glabra L.
}

\author{
Kriker Soulef ${ }^{\star}$, Y. Bouatrous, Ramazan Erenler* and A. Yahia** \\ Department of Natural Sciences and Life, University of Biskra - Algeria \\ * Department of Chemistry, Faculty of Arts and Sciences, Gaziosmanpasa University, 60240 Tokat, Turkey \\ ** Institute of Science and Technology, University Center of Mila, Algeria
}

\section{Article Info}

Article history

Received 10 August 2021

Revised 27 September 2021

Accepted 28 September 2021

Published Online 30 December 2021

\section{Keywords}

Glycyrrhiza glabra L.

Saponins

Tannins

Antioxidant activity

Antibacterial activity

Cytotoxic activity

\begin{abstract}
Glycyrrhiza glabra L. or licorice is a herbaceous plant of the family Fabaceae, used for millennia by traditional medicine. This plant contains saponins in the roots and tannins in the leaves and roots.

The objective of this study is to extract these two groups of secondary metabolites from roots and leaves of this plant collected from Rélizane region, in West of Algeria, as well as testing their antioxidant, antibacterial and anticancer activities on various pathogenic bacterial strains: Escherichia coli (ATCC 25922), Pseudomonas aeruginosa (ATCC 27853), Staphylococcus aureus (ATCC 25923), Bacillus subtilis (ATCC 21332), Enterococcus faecalis (ATCC 29212) and Salmonella typhimurium (ATTC 13311). The antioxidant activity was assessed by DPPH and ferric reduction antioxidant potential (FRAP) assay and saponins extract of root was found to possess higher antioxidant activity, indicating the presence of compounds effective in the chemical composition of the plant that has a high antioxidant capacity. We noted that Staphylococcus aureus appears to be more sensitive to the effect of saponins extract with 26 $\mathrm{mm}$ inhibition zones, whereas Escherichia coli is more sensitive to tannins extract $(14.10 \mathrm{~mm}$ for the extract of the roots and $15.33 \mathrm{~mm}$ for that of the leaves). The $\mathrm{IC}_{50}$ values on MCF-7 human breast cells were $649.696 \mu \mathrm{g} / \mathrm{ml}, 1003.33 \mu \mathrm{g} / \mathrm{ml}$ and $871.32 \mu \mathrm{g} / \mathrm{ml}$ by saponins, tannins of roots and tannins of leaves extracts, respectively. The $\mathrm{IC}_{50}$ values on L929 fibroblast cells were $334.71 \mu \mathrm{g} / \mathrm{ml}, 750.95 \mu \mathrm{g} / \mathrm{ml}$ and $669.52 \mu \mathrm{g} / \mathrm{ml}$ by saponins, tannins of roots and tannins of leaves extracts, respectively. The extracts of G. glabra significantly decreased the growth of breast cancer and fibroblast cells. The results of the study showed that the extracts may be used to treat some diseases but future research is needed.
\end{abstract}

\section{Introduction}

Algeria, by its geographical situation, vast surface area and varied environments, offers rich and diverse vegetation. A large number of aromatic and medicinal plants grow there spontaneously. The interest in these plants has not stopped growing in recent years. As part of the development of the Algerian flora, we were interested in species of the Fabaceae family which is one of the most used families as a global source of spices and extracts with high antioxidant, antimicrobial and antiproliferative properties.

The value of these medicinal plants is in certain chemicals that produce a definite physiological effect on the human body. The most important of these bioactive constituents are: triterpene, saponins, flavonoids, tannins, alkaloids and glycosides (Akinmoladun et al., 2007).

Licorice (Glycyrrhiza glabra L.) is one of the most commonly used medicinal plants in traditional medicine; it is a perennial of the Fabaceae family, with aromatic roots and is from Southern Europe and Asia (Al-Ani et al., 2008)

Corresponding author: Ms. Kriker Soulef

Department of Natural Sciences and Life, University of Biskra - Algeria E-mail: Soulefa2011@yahoo.fr; s.kriker@univ-biskra.dz Tel.: +23-1672506293
G. glabra has been considered an herbal medicine since antiquity. At present, it is a well-known spice that has noteworthy pharmacological effects. The beneficial properties attributed to licorice for human health are mainly: anti-inflammatory, laxative, immunomodulatory, antiucler, antitussive, antipyretic, anticancer, antioxidant and antimicrobial (Al-Obaidi, 2014).

Saponins and tannins are important biologically active components in plants. Not only do they have antibacterial activity, but also they have very important properties such as antioxidant, antifungal, antiinflammatory and anticancer, etc. These compounds are present in a large number of plants and these plants can be useful in many therapeutic conditions (Iş1l and Türkan, 2015).

In this context, the objective of this study is to evaluate the antioxidant, cytotoxic and antibacterial activities of extracts (tannins and saponins) of G. glabra from the Rélizane region in Algeria, so that it could be a guide in the discovery of a new molecule with the antioxidant, cytotoxic and antimicrobial property.

\section{Materials and Methods}

\subsection{Plant material used}

The studied species G. glabra was harvested from Rélizane region west of Algeria during October 2019. The used parts of the plant are: dry; roots and leaves. 


\subsection{Preparation of extracts}

\subsubsection{Preparation of licorice saponins extract}

Saponins are extracted according to the method described by Okwu and Josiah (2006), test portion of $20 \mathrm{~g}$ of the plant material of this plant was dispersed in $200 \mathrm{ml}$ of $20 \%$ ethanol. A first extraction was carried out in a water bath at $55^{\circ} \mathrm{C}$ without rotation for $4 \mathrm{~h}$. After filtration, the residue obtained was extracted a second time with 200 $\mathrm{ml}$ of a $20 \%$ ethanol solution, which was then filtered. The collected filtrates were concentrated in a water bath at $90^{\circ} \mathrm{C}$ to obtain a volume of $40 \mathrm{ml}$. In a separatory funnel, the concentrated solution is mixed with $20 \mathrm{ml}$ of diethyl ether, stirring vigorously. This operation was repeated three times. Then, the recovered aqueous phase was extracted with $20 \mathrm{ml}$ of $\mathrm{n}$-butanol. This operation was repeated three times. After that, the combined extracts of n-butanol were washed twice with $10 \mathrm{ml}$ of a $5 \%$ aqueous solution of $\mathrm{NaCl}$ and then heated in a water bath. After evaporation, the residues obtained was stored at $-18^{\circ} \mathrm{C}$.

\subsubsection{Preparation of licorice tannins extract}

The tannins are extracted according to the method of Bruneton (1999), $50 \mathrm{~g}$ of (roots or leaves) plant material was defatted with $75 \mathrm{ml}$ of petroleum ether for $6 \mathrm{~h}$ (He-Long et al., 2010). In a monocle balloon, $50 \mathrm{~g}$ of defatted plant material was placed in the presence of $125 \mathrm{ml}$ of distilled water and $80 \mathrm{ml}$ of acetone. The whole was macerated for four days. After filtration through filter paper and elimination of acetone by the rotary evaporator, the solution was extracted three times with $25 \mathrm{ml}$ of dichloromethane to remove the pigments and lipids. And decanted to extract the aqueous phase four times with $25 \mathrm{ml}$ of ethyl acetate, the organic phase was dried over $\mathrm{Na}_{2} \mathrm{SO}_{4}$, then filtered and evaporated. After evaporation, we obtain the tannins extract and the residues obtained was stored at $-18^{\circ} \mathrm{C}$.

\subsection{Antibacterial activity}

\subsubsection{Microbial strains tested}

Strains were identified and isolated at a Microbiology laboratory at the Biskra Hospital facility. They were subsequently stored in the refrigerator in test tubes containing agar slants. The pathogenic strains used are indicated in (Table 1).

Table 1: List of microbial strains tested

\begin{tabular}{|l|l|l|}
\hline Strains tested & Codes & Family \\
\hline Escherichia coli & ATCC 25922 & Enterobacteriaceae \\
\hline Pseudomonas aeruginosa & ATCC 27353 & Pseudomonadaceae \\
\hline Salmonella typhimurium & ATCC 13311 & Enterobacteriaceae \\
\hline Staphylococcus aureus & ATCC 25923 & Staphylococcaceae \\
\hline Bacillus subtilis & ATCC 21332 & Bacillaceae \\
\hline Enterococcus faecalis & ATCC 29212 & Enterococcaceae \\
\hline
\end{tabular}

2.3.2 The disc diffusion method for evaluation of the antimicrobial activity

The method of disc diffusion (Bauer et al., 1966; Rahman and Rashid, 2008) was used to test solutions of known concentration $(\mu \mathrm{g} / \mathrm{ml})$ of the tested extracts by dissolving the measured quantity of the extracts in calculated volume of dimethylsulfoxide (DMSO). Dried and sterilized filter paper discs (6 $\mathrm{mm}$ diameter) were then impregnated with known amounts of the test substances using a micropipette and the residual solvents were completely evaporated. Discs containing the test materials were placed on nutrient agar medium uniformly inoculated with the test microorganisms. Standard disc of Gentamicin $(10 \mu \mathrm{g} / \mathrm{disc})$ and blank discs (impregnated with DMSO followed by evaporation) were used as a positive and negative control, respectively. These plates were then kept at a low temperature $\left(4^{\circ} \mathrm{C}\right)$ for $24 \mathrm{~h}$ to allow maximum diffusion of the test materials and Gentamicin. The plates were then incubated at $37^{\circ} \mathrm{C}$ for $24 \mathrm{~h}$ to allow maximum growth of the organisms (NCCLS, 1997; 1999). Antimicrobial activity was evaluated by measuring the diameter of the zone of inhibition around the disc expressed in $\mathrm{mm}$. The assay was repeated three times and the mean diameter was recorded (Table 3).

\subsubsection{Determination of minimum inhibitory concentrations (MIC) and minimum bactericidal concentrations (MBC) tests}

The MIC is the lowest concentration of the substance for which there is no visible growth with the naked eye after an incubation time of 18 to $24 \mathrm{~h}$. Its determination was made by observation of the disorder induced by the growth of germs in each tube (Mobosso et al., 2010; Yamina, 2019). Broth microdilution was carried out in accordance with CLSI (2018). The plant extracts were dissolved in DMSO and then serially diluted with MHB from $50 \mathrm{mg} / \mathrm{ml}$ to 0.195 $\mathrm{mg} / \mathrm{ml}$ in triplicate in a 96-well plate. The final DMSO concentration in the assay did not exceed $5 \%$. The bacterial suspensions were added to the plate to obtain $\left(5 \times 10^{5} \mathrm{cfu} / \mathrm{ml}\right)$. The plates are incubated at $37^{\circ} \mathrm{C}$ for $24 \mathrm{~h}$. The lowest concentration of plant extract in the well with no visible turbidity was taken as the MIC.

$\mathrm{MBC}$ is the lowest concentration of antibiotic capable of killing bacteria after $24 \mathrm{~h}$ of incubation in a specific growth medium, leaving a percentage of surviving bacteria $<0.01 \%$ of the starting inoculum (Joffin and Leyral, 2006).

To determine the minimum bactericidal concentration, $3 \mu \mathrm{l}$ of suspensions from the clear wells were spread out on a blood agar plate and incubated at $37^{\circ} \mathrm{C}$ until sufficient growth was obtained. The lowest concentration that reduced the number of viable cells of the initial inoculum to $<0.01 \%$ was regarded as the MBC.

\subsection{Antioxidant activity}

\subsubsection{DPPH free radical-scavenging activity}

In order to study the anti-free radical activity of our extract, we used the DPPH-based method, according to the protocol of Masuda et al. (1999).

Evaluation of the free radical scavenging activity of the various extracts was performed by a modified quantitative DPPH $(1,1$-diphenyl-2picrylhydrazyl) assay. Different concentrations of extracts in methanol were provided $(0.25,0.5,1,1.5,2,2.5,3,3.5,4,4.5$, and $5 \mathrm{mg} / \mathrm{ml}$ ). Blank samples were run by $1 \mathrm{ml}$ methanol instead of the sample, then $1 \mathrm{ml}$ of $0.004 \%$ DPPH in methanol was mixed with 1 $\mathrm{ml}$ of the test solution, or standard, and diluted with $1 \mathrm{ml}$ of methanol. The mixture was left to stand at room temperature in the dark for 30 min.The change in colour from deep violet to light yellow was then evaluated at $517 \mathrm{~nm}$. Inhibition of free radicals in percentage (I \%) was determined based on the following equation:

$$
\mathrm{I} \%=\left(\left(\mathrm{A}_{0}-\mathrm{A}_{1}\right) / \mathrm{A}_{0}\right) \times 100
$$


where $\mathrm{A}_{0}$ is the absorbance of the control reaction (including all reagents except the sample) and $A_{1}$ is the absorbance of the extract.

Extract concentration providing $50 \%$ inhibition $\left(\mathrm{IC}_{50}\right)$ was measured from the graph plotted of inhibition percentage against extract concentration. According to Laib (2011), the lower $\mathrm{IC}_{50}$ value indicated the higher antioxidant activity. BHT (butylated hydroxytoluene) was used as a positive control. Measurements were done in triplicates.

\subsubsection{Ferric reducing antioxidant power (FRAP)}

The reducing power was obtained according to the method of Oyaizu (1986) with slight modifications. Various concentrations of extracts were mixed with $2.5 \mathrm{ml}$ of $0.2 \mathrm{M}$ phosphate buffer and potassium ferricyanide (1\%). The mixture was incubated at $50^{\circ} \mathrm{C}$ for $20 \mathrm{~min}$. After the incubation, $2.5 \mathrm{ml}$ of $10 \%$ trichloroacetic acid was added. $2.5 \mathrm{ml}$ of the reaction mixture was mixed with $2.5 \mathrm{ml}$ of distilled water and $0.5 \mathrm{ml}$ of ferric chloride $(0.1 \%)$. The absorbance of the solution is measured at $700 \mathrm{~nm}$. The increase in the absorbance of the reaction mixture indicates an increase in reducing power.The same procedure was applied with ascorbic acid or standard.

\subsection{Antiproliferative assays}

\subsubsection{Preparation of cell culture}

Frozen cells were thawed rapidly at $37^{\circ} \mathrm{C}$; thawed inside a sterile laminar flow cabin, the cells were transferred to a $15 \mathrm{ml}$ falcon tube and centrifuged at 2,500 rpm for $2 \mathrm{~min}$. A total of $3 \mathrm{ml}$ of DMEM (Caprion, CANADA) (10\% FBS (Caprion, CANADA), \%1 antibiotic (Biological Industries, USA)) (for L929), RPMI 1640 (Biological Industries, USA) (10\% FBS, \%1 antibiotic) (for H1299, MCF-7 and A549) mediums were added to the falcon tube and after allowing homogenization, cells were seeded into $25 \mathrm{~cm}^{2}$ flasks. The flasks were left to incubate at $37^{\circ} \mathrm{C}$ and $5 \% \mathrm{CO}_{2}$. After $72 \mathrm{~h}$, cells were scraped with $1 \mathrm{ml}$ of Trypsin and EDTA (Biological Industries, USA) for 4 min and then the cells were transferred to a $15 \mathrm{ml}$ falcon tube and centrifuged at 2,500 rpm for $2 \mathrm{~min}$.

\subsubsection{MTT cytotoxicity tests}

MTT assay for cytotoxicity, MCF-7 human breast cancer cells and L929 fibroblast cells $\left(5 \times 10^{3}\right.$ cells/well $)$ were seeded into flatbottomed 96-well plates containing DMEM with L-glutamine and $10 \%$ FBS supplemented with 1\% PS (Pen and Strep), RPMI 1640 with L-glutamine and 10\% FBS supplemented with 1\% PS (Pen and Strep) and incubated over night. Following this incubation, particles with different concentrations : $1500 \mu \mathrm{g} / \mathrm{ml}, 1000 \mu \mathrm{g} / \mathrm{ml}, 750 \mu \mathrm{g} / \mathrm{ml}$, $500 \mu \mathrm{g} / \mathrm{ml}, 250 \mu \mathrm{g} / \mathrm{ml}, 100 \mu \mathrm{g} / \mathrm{ml}, 25 \mu \mathrm{g} / \mathrm{ml}, 5 \mu \mathrm{g} / \mathrm{ml}$ were diluted with cell culture medium and inoculated into the wells. The plates were kept in the $\mathrm{CO}_{2}$ incubator at $37^{\circ} \mathrm{C}$ in $5 \% \mathrm{CO}_{2}$ for $24 \mathrm{~h}$. The cell culture medium was substituted with $100 \mu \mathrm{l}$ fresh medium and $15 \mu \mathrm{l}$ of fresh MTT solutions and incubated under the same circumstances for $4 \mathrm{~h}$ a dark state. After that, $100 \mu \mathrm{l}$ is opropanol-HCl to dissolve the formed dark blue for mazancrsytals was added to each well and incubated for $30 \mathrm{~min}$ in a dark condition. The wells were read by the ELISA plate reader using a Spectra Max 190 microplate reader (Molecular Devices, Sunnyvale, CA) at $570 \mathrm{~nm}$. The number of living and dead cells was counted using a cell counter. Each assay was repeated three times. The cytotoxicity test was done in triplicate and the relative cell viability (\%) was calculated as follows:

$$
\text { Cell viability }(\%)=[\mathrm{A}]_{\text {sample }} /[\mathrm{A}]_{\text {control }} \times 100
$$

where $[\mathrm{A}]_{\text {sample }}$ is the absorbance of the test sample and $[\mathrm{A}]_{\text {control }}$ is the absorbance of the control sample.

\subsection{Statistical analysis}

All experiments were carried out in triplicate. Data are expressed as Mean $\pm \mathrm{SD}$. Differences were evaluated by one-way ANOVA test using the Statistical Package for Social Sciences (Windows version 21.0: SPSS). $p<0.05$ was considered as significant for all the tests.

\section{Results}

\subsection{Determining of extraction yield}

After extraction, the saponins and tannins extraction yield of the plant studied (G. glabra) was determined in (Table 2).

Table 2: Saponins and glycosides extraction yield

\begin{tabular}{|l|c|c|}
\hline Yield & Roots & Leaves \\
\hline Saponins extract & $4.2 \%$ & - \\
Tannins extract & $1.58 \%$ & $1.42 \%$ \\
\hline
\end{tabular}

In general, the contents of dry extracts vary not only from one plant to another of the same family, but also according to different parts of the plant (leaves or roots).

Saponins are found only in the root of licorice; they are triterpene structures, mainly represented by glycyrrhizin (3 to 5\%) of the dry drug (Gily, 2005).

\subsection{Antibacterial activity of saponins and tannins extracts}

At the end of $24 \mathrm{~h}$, statistically significant antimicrobial activity was demonstrated by all the test specimens used in this study $(p<0.05)$.

This antibacterial activity was quantitatively determined by the presence or absence of an inhibition zone around the discs containing the extract. All the data are presented in Table 3 (Results were reported as the mean values of three different experiments).

According to the results obtained (Table 3), the largest zone of inhibition obtained with the saponins extracts on Staphyloccocus aureus $(26.0 \pm 0.0 \mathrm{~mm})$ and slightly active on Pseudomonas aeruginosa $(8.0 \pm 1.0 \mathrm{~mm})$, while the tannins leave extracts had a big effect on S. aureus $(19.0 \pm 0.56 \mathrm{~mm})$, followed by Bacillus subtilis $(18.33 \pm 0.0 \mathrm{~mm})$. On the other hand; the tannins roots extract showed maximum inhibitory effect against Bacillus subtilis (16.67 \pm $0.58 \mathrm{~mm})$, followed by Escherichia coli $(15.10 \pm 1.0 \mathrm{~mm})$ compared with Gentamicin as a positive standard.

The values of minimum inhibitory concentration (MIC) and minimum bactericidal concentration (MBC) of saponins and tannins extract of G. glabra plant against tested bacteria showed that the saponins and tannins extract on gram-positive bacteria have a higher bactericidal potency than gram-negative bacteria. These results indicate that there is a significant difference in the susceptibility of G. glabra among the bacteria $(p<0.05)$.

All tested strains were sensitive to all tested extracts with MICs ranged from $0.78 \mathrm{mg} / \mathrm{ml}$ (saponins extract) up to $25 \mathrm{mg} / \mathrm{ml}$ (tannins roots extract) and $\mathrm{MBCs}$ from $1.56 \mathrm{mg} / \mathrm{ml}$ (saponins extract) up to $100 \mathrm{mg} / \mathrm{ml}$ (for tannins leaves extract) (Table 4). However, saponins extract showed the most favorable results as the lowest both MIC and $\mathrm{MBC}(0.78 \mathrm{mg} / \mathrm{ml}$ and $1.56 \mathrm{mg} / \mathrm{ml}$, respectively) against $S$. aureus with highly significant differences $p<0.01$ (Table 4 ). 
Table 3: Antibacterial activity expressed as mean \pm SD of growth inhibition zone diameters (mm) of $G$ glabra extacts

\begin{tabular}{|l|c|l|l|c|c|}
\hline \multirow{2}{*}{ Extracts } & Saponins roots extracts & \multicolumn{2}{|c|}{ Tannins extracts } & \multirow{2}{*}{ DMSO } & \multirow{2}{*}{ Gentamycin } \\
\cline { 3 - 4 } Strains tested & & Roots & Leaves & & \\
\hline Escherichia coli & $13.33 \pm 0.58$ & $15.10 \pm 1.0^{*}$ & $15.33 \pm 1.0^{*}$ & - & $28.00 \pm 1.0$ \\
Pseudomonas aeruginosa & $08.0 \pm 1.0$ & $08.33 \pm 0.58$ & $10.00 \pm 0.58$ & - & $18.57 \pm 0.58$ \\
Salmonella typhimurium & $11.5 \pm 0.58$ & $11.50 \pm 0.5$ & $13.25 \pm 1.0$ & - & $19.67 \pm 0.58$ \\
Staphylococus aureus & $26.0 \pm 0.0^{* *}$ & $14.33 \pm 0.01$ & $19.00 \pm 0.56^{* *}$ & - & $32.00 \pm 1.0$ \\
Bacillus subtilis & $16.67 \pm 0.52^{*}$ & $16.67 \pm 0.58^{*}$ & $18.33 \pm 0.0^{*}$ & - & $22.83 \pm 0.29$ \\
Enterococcus faecalis & $18.10 \pm 0.29^{*}$ & $15.00 \pm 0.00^{*}$ & $16.50 \pm 1.0^{*}$ & - & $26.00 \pm 1.0$ \\
\hline
\end{tabular}

*Significant at 0.05 level, ** Significant at 0.01 level, mean \pm SD (Standard deviation)

Table 4 : Minimum inhibitory concentration [MIC $(\mathrm{mg} / \mathrm{ml})$ and $\mathrm{MBC}(\mathrm{mg} / \mathrm{ml})$ ] of saponins and tannins extracts

\begin{tabular}{|l|c|c|c|c|c|c|}
\hline \multirow{2}{*}{ Extracts } & \multicolumn{2}{|c|}{ Saponins extracts } & \multicolumn{4}{|c|}{ Tannins extracts } \\
\cline { 2 - 6 } & MIC & MBC & \multicolumn{2}{|c|}{ MIC } & \multicolumn{2}{c|}{ MBC } \\
\cline { 4 - 7 } & & & Roots & Leaves & Roots & Leaves \\
\hline E. coli & $6.25 \pm 0.023$ & $12.50 \pm 0.08$ & $12.50 \pm 0.001$ & $6.25 \pm 0.025$ & $25.00 \pm 0.014$ & $12.50 \pm 0.025$ \\
P. aeruginosa & $12.5 \pm 0.002$ & $25.00 \pm 0.001$ & $25.00 \pm 0.003$ & $12.5 \pm 0.018$ & $50.00 \pm 0.001$ & $10.00 \pm 0.001$ \\
S. typhimurium & $6.25 \pm 0.001$ & $12.50 \pm 0.002$ & $12.50 \pm 0.001$ & $6.25 \pm 0.001$ & $25.00 \pm 0.001$ & $12.50 \pm 0.003$ \\
S. aureus & $0.78 \pm 0.003^{* *}$ & $1.56 \pm 0.012^{* *}$ & $6.25 \pm 0.014^{*}$ & $3.125 \pm 0.05 *$ & $6.25 \pm 0.08 *$ & $3.125 \pm 0.005 *$ \\
B. subtilis & $3.125 \pm 0.001 *$ & $6.25 \pm 0.014^{*}$ & $6.25 \pm 0.011^{*}$ & $3.125 \pm 0.02 *$ & $6.25 \pm 0.147 *$ & $6.25 \pm 0.023 *$ \\
E. faecalis & $01.56 \pm 0.011^{* *}$ & $3.125 \pm 0.02 * *$ & $3.125 \pm 0.01 *$ & $6.25 \pm 0.024 *$ & $6.25 \pm 0.001 *$ & $3.125 \pm 0.002 *$ \\
\hline
\end{tabular}

$*$ Significant at 0.05 level, $* *$ Significant at 0.01 level, mean \pm SD (Standard deviation)

Table 5: IC $_{50}$ DPPH test of saponins and tannins extracts

\begin{tabular}{|l|l|c|c|c|}
\hline $\begin{array}{l}\text { Extracts } \\
\mathbf{I} \mathbf{C}_{\mathbf{5 0}}(\mathbf{m g} / \mathbf{m l})\end{array}$ & Saponins of roots & Tannins of roots & Tannins of leaves & Ascorbic acid \\
\hline $\mathrm{DPPH}$ & $0.65 \pm 0.05^{* *}$ & $0.75 \pm 0.06^{* *}$ & $1.02 \pm 0.08^{*}$ & $0.66 \pm 0.09^{* *}$ \\
\hline
\end{tabular}

*Significant at 0.05 level, $* *$ Significant at 0.01 level, mean \pm SD (Standard deviation)

\subsection{Antioxidant Activity}

In the case of antioxidant screening (Table 5), antioxidant activity is defined as the ability of a compound to inhibit oxidative degradation, such as lipid peroxidation and is widely used as a parameter for medicinal bioactive components. The (DPPH) free radical scavenging activity method showed antioxidant activity with $\mathrm{IC}_{50}$ value of 0.65 $\mathrm{mg} / \mathrm{ml}$ for saponins extract, $0.75 \mathrm{mg} / \mathrm{ml}$ for tannins roots extracts and $1.02 \mathrm{mg} / \mathrm{ml}$ for tannins leaves extracts. Standard ascorbic acid had the $\mathrm{IC}_{50}$ value of $0.66 \mathrm{mg} / \mathrm{ml}$

The reducing capacity of compound $\mathrm{Fe}^{3}$, ferricyanide complex to the ferrous form may serve as a significant indicator of its antioxidant capacity (Yildirim et al., 2001). Figure1 shows the dose response curves for the reducing power of the extracts from G. glabra root and leaves as a function of their concentration. In this study, the reductive ability of saponins and tannins extracts and standard antioxidant (Ascorbic acid) was measured by investigating the $\mathrm{Fe}^{+3} \rightarrow \mathrm{Fe}^{+2}$ transformations according to the method of Oyaizu (1989). The reducing power of these entire test compounds increased in a concentration in dependent manner. Saponins licorice root extract showed higher reducing power, compared to tannins extracts.
The result for ferric ion reducing power (A700 nm, 0.50) was found in the saponins extract while the values for ferric ion reducing power was found in the tannins of roots extract (A700 nm, 0.2) and the tannins of leaves extract (A700 nm, 0.28) at the concentration 250 $\mu \mathrm{g} / \mathrm{ml}$. The reducing powers of all licorice extracts were markedly lower than that of ascorbic acid (Figure 1).

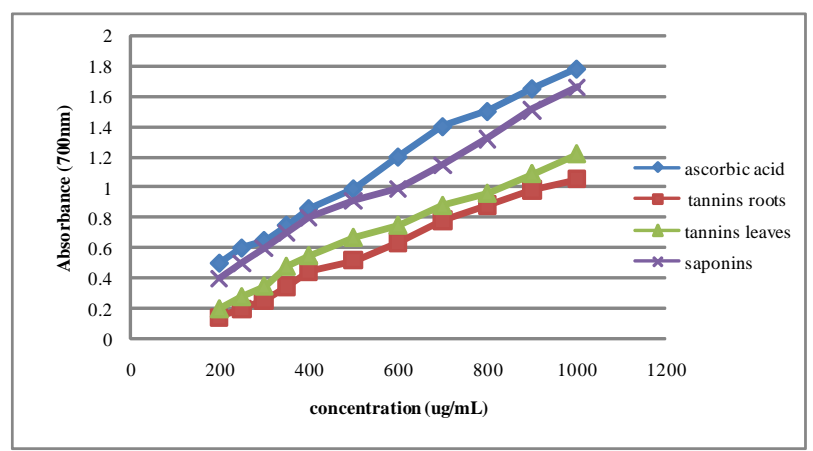

Figure 1: Reducing powers of saponins and tannins extracts of licorice and ascorbic acid. Values are significantly different $(p<0.05)$ from each other. 


\subsection{In vitro cytotoxicity analysis}

The cytotoxic potential of saponins and tannins extracts of G. glabra were shown in Figures 2 and 3 after 24 h incubation period on L929 fibroblast cells and MCF-7 human breast cells, respectively. The percentage of surviving cells decreased in comparison to the control group with increasing the concentration of saponins and tannins (roots and leaves) extracts. Figure 2 shows that more than $50 \%$ of L929 cells were decreased in concentrations of (250, 500 and 750) $\mu \mathrm{g} / \mathrm{ml}$ for saponins, tannins roots and tannins leaves extracts, respectively. Figure 3 shows that more than $50 \%$ of MCF-7 cells were decreased in concentrations of $500 \mu \mathrm{g} / \mathrm{ml}$ and $1000 \mu \mathrm{g} / \mathrm{ml}$ for saponins and tannins extracts, respectively.

The $\mathrm{IC}_{50}$ values of G. glabra 929 fibroblast cells were $334.71 \mu \mathrm{g} /$ $\mathrm{ml}, 750.95 \mu \mathrm{g} / \mathrm{ml}$ and $669.52 \mu \mathrm{g} / \mathrm{ml}$ by saponins, tannins roots and tannins leaves extracts, respectively. The $\mathrm{IC}_{50}$ values of G. glabra MCF-7 cells were $649.696 \mu \mathrm{g} / \mathrm{ml}, 1003.33 \mu \mathrm{g} / \mathrm{ml}$ and $871.32 \mu \mathrm{g} / \mathrm{ml}$ by saponins, tannins roots and tannins leaves extracts, respectively.

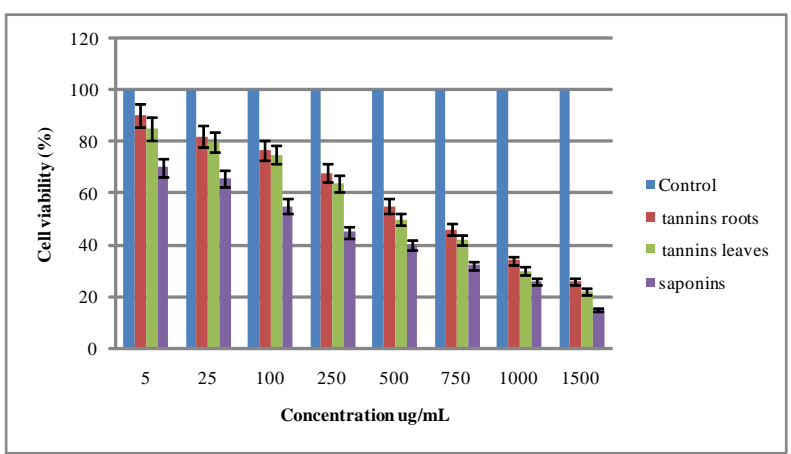

Figure 2: The percentage of survival of L929 fibroblast cells exposed to saponins and tannins extracts of G. glabra during $24 \mathrm{~h}$ incubation period.

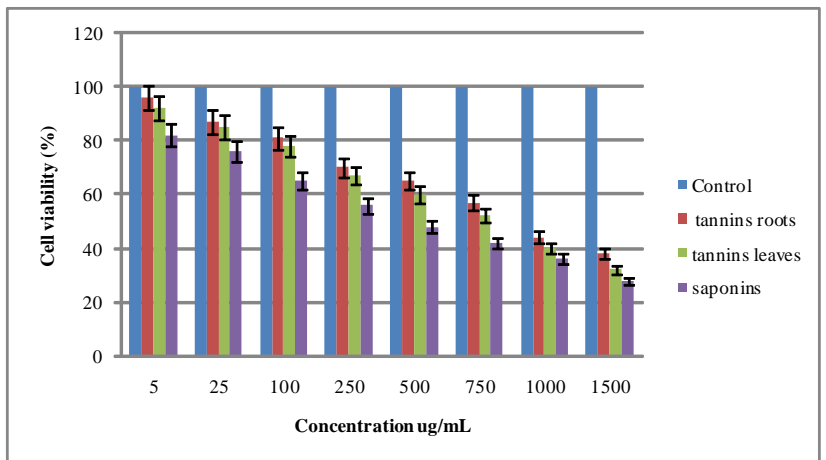

Figure 3: The percentage of survival of MCF-7 human breast cells exposed to saponins and tannins extracts of G. glabra during $24 \mathrm{~h}$ incubation period.

\section{Discussion}

\subsection{Saponins and tannins extraction yield}

We can say that our results are not in agreement with the results of Al Obaidi (2014), which estimated that the yield of saponins extracts of G. glabra from the Iraq region is $41.1 \%$ which greatly exceeds the result obtained in this study (4.2\%). This difference can be explained by the different climatic conditions of this region compared to that of Algeria.

According to Gily (2005), the harvest period depends on the nature of the soil and the variety. This difference could also be explained by Kelen and Tepe (2008), about the choices of the harvest period because it is essential in terms of yield and quality of plant extract, climate, geographic area, the organ of the plant used, the drying period, the extraction method; these are factors among others that can have a direct impact on the yields of plant extract.

\subsection{Antibacterial activity}

Plants have developed natural defence mechanisms to protect themselves long before man played an active role in protecting them. It is known that plants synthesize a variety of groups of bioactive compounds in plant tissues as secondary metabolites that have an antimicrobial activity to stop or inhibit the development of germination of pathogens (Santos et al., 2009) .

The phytochemical screening of the root of G. glabra revealed the presence of phenolic compounds, flavonoids, alkaloids, glycosides, carbohydrates, starches, proteins, pectin, mucilage, saponins, lipids, tannins, steroids and sterols. It has shown improved memory, antidepressant, antioxidant, anticancer, antimicrobial, protective, antiulcer, antidiabetic, hypolipidemic, anti-inflammatory, and many other pharmacological effects.

The results of this study indicated that all extracts had an antimicrobial effect against all microorganisms tested. The antibacterial activity of saponins extract is possibly linked to the presence of glycyrrhizin in liquorice root which is a triterpenoid saponin glycoside (4-20\%), a mixture of potassium and calcium salts of $18 \beta$-glycyrrhizic acid (which was the main bioactive compound in underground parts, also called glycyrrhizic or glycyrrhizic acid and a glycoside of glycyrrhetinic acid), it was fifty times sweeter than sugar. Licorice root also contained other triterpenes including glycyrretol, glabrolide, liquiritic acid, isoglaborlide and liquorice acid. $18 \beta$-glycyrrhizic acid (3-O-(2-O- $\beta$-d-glucopyranuronosyl - $\alpha$ dglucopyranurosyl)-3$\beta$-hydroxy-11-oxo-18 $\beta, 20 \beta$-olean-12-in-29-oic acid) was isolated from G. glabra roots (Benigni et al.,1969 ; Isbrucker and Burdock, 2006). According to Soulef et al. (2014), the antibacterial effect of the glycosides extracted from G. glabra roots was investigated against three bacterial strains, Escherichia coli, Pseudo-monas aeruginosa and Staphylococcus aureus. They showed an inhibitory effect on the gram-positive strain (Staphylococcus aureus ATCC 23) and gram-negative strain (Pseudomonas aeruginosa ATCC53), but it possessed no effect on Escherichia coli ATCC22 strain. The antimicrobial activity of G. glabra is well known and glabridin and glycyrrhizin (saponin) have been reported to possess antibacterial activities against some strains (Garnier et al., 1961; Demizu et al.,1988 ; Haraguchi et al.,1998, Yokota et al.,1998).

The tannic compound, in general, has good activity against bacterial growth and this is because these compounds contain titanic acid against certain kinds of diseased bacteria tanks to the ability of these compounds to dissolve the fatty layer of diseased bacterial wall that causes leakage of cell fluid out the cell and destroys it. And has the ability to consist the hydrogen bond between $\mathrm{OH}$ group in phenol compound that includes tanic acid, the nitrogen of amino acid in bacterial cell that lead to loss of this activity which leads to loss of vital action of cell and destroys it (Aqeel et al.,1989; Al-Ani et al., 
2008 ). In most often, the leaf extracts had better activity than the root extracts. Tannins extracts from leaves of G. glabra showed the highest activity compared with tannins of roots. The purified tannins extracted from a plant containing the tannin exhibited a range of microbial activity. The tannins obtained from the leaves had greater antimicrobial activity than the other types of tannins and this result is the same as our result noted that the extract of the leaves has a high antibacterial activity than the extract of the roots (Min et al., 2008).

Castillo et al. (2012) stated three hypotheses that could explain the antimicrobial mechanism of tannins: inhibition of enzymatic activity by complexion with substrates of bacteria and fungi; direct action of tannins on the microorganism metabolism, through the inhibition of oxidative phosphorylation; a mechanism involving the complexion of tannins with metabolic ions, decreasing the availability of essential ions to the metabolism of the microorganisms. Saponins are active due to causing leakage of proteins and certain enzymes (Zabloto wicz et al., 2009; Patil et al., 2009), and tannins bind to prolin rich proteins and interfere with the protein synthesis (Shimada, 2006).

\subsection{Antioxidant activity}

The reducing power of the species G. glabra is probably due to the presence of hydroxyl group in the phenolic compounds which can serve as electron donors. Antioxidants can, therefore be considered as reducing and inactivating oxidants (Siddhuraju and Becker, 2007). It has been shown that antioxidant molecules such as ascorbic acid, tocopherol, flavonoids, saponins and tannins reduce and discolour the $\mathrm{DPPH}$, due to their ability to give up the hydrogen (Bougandoura and Bendimerad, 2013; Punit et al., 2019). On the other hand, rich phenolic contents of the extracts may probably contribute strong neuroprotective and antioxidant activities to the plant (Sevgi et al., 2020).

Various licorice compounds exert an antioxidant action that is responsible for several activities. Yokozawa shows that rats, who received licorice extract before undergoing oxidative stress, see a significant reduction in nitrates and nitrogen monoxide, resulting from the reduction of nitrates. In addition, he observed a decrease in the level of nitrotyrosine, a specific marker for the oxidative activity of enzymes. Yokosawa has identified the active principles behind these properties: it is glycyrrhizin (saponin) (Yokozawa et al., 2005).

The antioxidant activity of phenolic compounds was correlated with their chemical structures and degrees of polymerisation ( $\mathrm{Lu}$ and Foo, 2000). Hagerman et al. (1998) provided insights into the mechanism of procyanidin as the potential antioxidants, which showed that hydroxyl groups were important factors for free radical scavenging by tannins.

The reduction capacity of a compound may serve as asignificant indicator of its potential antioxidant activity (Meir et al.,1995). A greater absorbance corresponds to a higher ferric reducing power. The antioxidant activity has been reported to be concomitant with the development of reducing power (Akinmoladun et al., 2007). However, tannins can chelate metal ions such as Fe (II) and interfere with one of the reaction steps in the fenton reaction and thereby retard oxidation (Karamac et al., 2006).

\subsection{Cytotoxicity assay}

Licorice has been used extensively as a flavoring and sweetening agent in tobacco products, candy, toothpaste, chewing gum, and beverages, and it has been prescribed for a long time as a treatment in oriental herbal medicine. Licorice root is also recognized by the National Cancer Institute as exerting cancer chemopreventive effects (Chen and Han,1994 ; Fu et al., 2004).

The results of the above cytotoxic effect of the two extracts (saponins and tannins) from the root and leaves evaluated against two cancer cells, highlights, on the one hand, the important cytotoxic effect that G. glabra root and leaves extracts to exert against the two cancer cell lines evaluated with a more potent effect against L929 fibroblast cells as compared with MCF-7 human breast cells. On the other hand, the results indicate a variable potency among extracts, with saponins presenting the strongest cytotoxic effect against both cell lines.

Saponins have been ascribed to a number of pharmacological actions, such as immunomodulatory potential via cytokine interplay (Pizzi, 2008) cytostatic and cytotoxic effects on malignant tumour cells (Bachran et al., 2008).

Glycyrrhizin, is a triterpene saponin glycoside that is the main compound in root extract and acts as an anti-proliferative agent against tumour cells, especially breast cancer cell line (MCF-7) and HEP-2 and plays its role by inducing apoptosis (Baltina, 2003 ; Rossi et al., 2016). G. glabra root extract induces apoptosis in HT29 cells; therefore, it is useful in the treatment of colon cancer (Nourazarian et al., 2016).

In 1994, Chen and Han observed the effect of glycyrrhetic acid (saponin) of G. glabra on mouse tumours induced by a carcinogen, benzo $[\alpha]$ pyrene. This study made it possible to highlight part of the mechanism of action of this aglycone on tumors: glycyrrhetic acid would inhibit 20 to $80 \%$ of the activity of ornithine decarboxylase, which is responsible for cell proliferation. Regulation of this enzyme stimulates interleukin 1 and TNF (Tumour Necrosis Factor), and thus limits the development of cancer tissue (Chen and Han, 1994).

In May 2008, Hawthorne and Gallagher observed in a study realized in vitro, that glycyrrhetic acid had antitumour activity in androgendependent prostate cancer but lacking activity in non-androgendependent prostate cancer (Hawthorne and Gallagher, 2008).

In a published work, saponins have been determined to have antitumor properties in human colon cancer HT-29 cells and tumor xenografts. They inhibit cellular proliferation by accumulation in $\mathrm{S}$ phase and G2/M arrest, with concomitant suppression of p21 expression and inhibition of cyclin-dependent kinase activity. In addition, AST promotes apoptosis in HT-29 cells through caspase 3 activation and poly (ADP-ribose) polymerase cleavage, which is indicated by DNA fragmentation and nuclear condensation of chromatin (Tin et al., 2007).

There has been a great deal of interest in free radicals and oxygen species generated in vivo, which have been implicated in diseases such as cancer, multiple sclerosis, and atherosclerosis. Agents that cause oxidative DNA damage generally increase the risk of cancer development (Halliwell, 2002). Hydrolyzable tannins have been found to exhibit higher cytotoxicity against human oral squamous 
cell carcinoma and salivary gland tumour cell lines than against normal gingival fibroblasts (Sakagami et al., 2000).

Tannic acid was shown to possess anticarcinogenic activity against to hepatic neoplasms (adenomas plus carcinomas). Consequently, this component, therefore, exhibited chemoprotective activity (Nepka et al.,1999).

In a study, gallotannins were found to inhibit proliferation and induce apoptosis in a human colon cancer cell line (T-84) (Gali-Muhtasib et al., 2001). Fifty seven tannins and related compound, including ellagitannin, gallotannin and complex tannins, have been evaluated for their cytotoxicity against human tumour cells which are malignant melanoma, lung cancer, ilolecal adenocarcinoma, medulloblastoma cells and epidermoid carcinoma (Kashiwada et al.,1992). It was determined that tannins were exhibited antitumour and anticancer activity against HeLa cell and murine leukaemia cells (L1210/0), murine mammary carcinoma cells (FM3A), MCF7/HER2 and JIMT-1 breast cancer cells and human T-lymphocyte cells (Molt 4/C8, CEM/ 0) (Pizzi, 2008).

\section{Conclusion}

The present study revealed that saponins and tannins extracts of G. glabra roots and leaves showed better or close some antimicrobial and antioxidant activities. In our results, the saponins root extract of G. glabra showed better antioxidant activity than tannins extracts and also had a higher cytotoxic effect on L929 fibroblast cells and MCF-7 human breast cells, respectively. For this reason, it is possible to use these extracts in some diseases like cancer. The obtained results show that G. glabra contains very important components (saponins and tannins), which indicate that roots and leaves of this plant could be considered as potential phytoremedy for the development of novel agents in disorders in the coming years. In this regard, further studies need to be carried out to explore G. glabra for its ability to prevent and treat diseases.

\section{Acknowledgements}

The authors are grateful to the research section, Department of Chemistry, Faculty of Arts and Sciences, Gaziosmanpasa University, Tokat, Turkey and Department of Natural Sciences and Life, University of Biskra, Algeria for their valuable supports.

\section{Conflict of interest}

The authors declare no conflicts of interest relvant to this article.

\section{References}

Akinmoladun, A.C.; Ibukun, E.O.; Afor, E.; Akinrinlola, B.L.; Onibon, T.R.; Akinboboye, A.O.; Obutor, E.M. and Farombi, E.O. (2007). Chemical constituents and antioxidant activity of Alstonia boonei. African Journal of Biotechnology, 6(10):1197-1201.

Al-Ani, R.T.; Mohammed, N.; Atheer,A.A. and Mohammed, S. (2008). Antibacterial activity of tannins extracted from some medicinal plants in vitro. Al-Anbar Medical Journal, 6(1):1-7.

Al-Obaidi, O.H.S. (2014). Aqueous and alcoholic extracts from Glycyrrhiza glabra L. and theirs activity against bacteria and rhabdomyo sarcomas. European Chemical Bulletin, 3(2):133-137.

Aqeel, A. ; Kursheed, A.K. and Sabiha, Q. (1989). Antimicrobial activity of julifloricine isolated from Prosopis juliflora. Arzneimittel-forschung, 39(6):652-655.
Bachran, C. ; Bachran, S. ; Sutherland, M. ; Bachran, D. and Fuchs, H. (2008). Saponins in tumor therapy. Mini Reviews in Medicinal Chemistry, 8(6):575-584.

Baltina, L.A. (2003). Chemical modification of glycyrrhizic acid as a route to new bioactive compounds for medicine. Current Medicinal Chemistry, 10(2):155-171.

Bauer, A.W.W.M. ; Kirby, W.M.M. and Sherris, J.C.T. (1966). Antibiotic susceptibility testing by standardized single disc diffusion method. American Journal of Clinical Pathology, 45(4):493-496.

Benigni, R.; Capra, C. and Cattorini, P.E. (1964). Piante medicinali - Chimica Farmacologiae Terapia. Inverni and Della Beffa. Milano, 2:840866.

Bougandoura, N. and Bendimerad, N. (2013). Evaluation de l'activité antioxydante des extraits aqueux et méthanolique de Satureja calamintha ssp. Nepeta (L.) Briq. Nature et Technologie, 9:14-19.

Bruneton, J. (1999). Technique et Documentaire. Pharmacognosie. $3^{\text {ème }}$ édition, Paris, pp:691-694.

Castillo, F.; Hernández, D.; Gallegos, G.; Rodríguez, R. and Aguilar, C.N. (2012). Antifungal properties of bioactive compounds from plants, in fungicides for plant and animal diseases. Intech. Open, pp:81-106.

Chen, X.G. and Han, R. (1994). Effect of glycyrrhetinic acid on DNA damage and unscheduled DNA synthesis induced by benzo (á) pyrene. Acta Pharmaceutica Sinica, 29(10):725-729.

Clinical and Laboratory Standards Institute (2018). Methods for dilution antimicrobial susceptibility tests for bacteria that grow aerobically; Approved Standard, 11 th ed. CLSI document M07-A10; Clinical and Laboratory Standards Institute: Wayne, Pennsylvania 19087, USA., 38:1-91.

Cuendet, M. ; Guo, J.; Luo, Y.; Chen, S.; Oteham, C.P.; Moon, R.C.; van Breemen, R.B.; Marler, L.E.and Pezzuto, J.M. (2010). Cancer chemopreventive activity and metabolism of isoliquiritigenin, a compound found in licorice. Cancer Prevention Research, 3:221-232.

Demizu, S.; Kajiyama, K.; Takahashi, K.; Hiraga, Y.; Yamamoto, S.; Tamura, Y.;Okada, K. and Kinoshita, T. (1988). Antioxidant and antimicrobial constituents of licorice: Isolation and structure elucidation of a newbenzofuran derivative. Chemical and Pharmaceutical Bulletin, 36(9):3474-3479.

Fu, Y.; Hsieh, T.C.; Guo, J.; Kunicki, J.; Lee, M.Y.; Darzynkiewicz, Z. and Wu, J.M. (2004). Licochalcone-A, a novel flavonoid isolated from licorice root (Glycyrrhiza glabra), causes G2 and late-G1 arrests in androgenindependent PC-3 prostate cancer cells. Biochemical and Biophysical Research Communications, 322(1):263-270.

Gali-Muhtasib, H.U.; Younes, I.H.; Karchesy, J.J. and El-Sabban, M.E. (2001). Plant tannins inhibit the induction of aberrant crypt foci and colonic tumors by 1,2-dimethylhydrazine in mice. Nutrition and Cancer, 39(1): 108-116.

Garnier, G.; Bezanger-Beauqesne, L. and Debraux, G.(1961). Ressources médicinales de la flore française. tome II. Vigot Frères, Paris, 1506 $\mathrm{p}$.

Ghader, J.A.; Vahid, N.; Ehsan, A.; Mostafa, M. and Hadi, K. (2015). Antiulcer properties of Glycyrrhiza glabra L. extract on experimental models of gastric ulcer in mice. Iranian Journal of Pharmaceutical Research, 14(4): $1163-1170$.

Gily, G. (2005). Les plantes aromatiques et les huiles essentielles $\gamma$ grasse. Botanique-culturechimie-production et marché. Ed. Lharmattan, Paris, pp:101-160. 
Hagerman, A.E.; Riedl, K.M.; Jones, G.A.; Sovik, K.N.; Ritchard, N.T.; Hartzfeld, P.W. and Riechel, T.L. (1998). High molecular weight plant polyphenolics (tannins) as biological antioxidants. Journal of Agricultural and Food Chemistry, 46(5):1887-1892.

Halliwell, B. (2002). Effect of diet on cancer development: Is oxidative DNA damage biomarker? Free Radical Biology and Medicine, 32(10): 968-974.

Haraguchi, H.; Ishikawa, H.; Mizutani, K.; Tamura, Y. and Kinoshita, T. (1998) Antioxidative and superoxide scavenging activities of retrochalcones in Glycyrrhiza inflata. Bioorganic and Medicinal Chemistry, 6(3): 339-347.

Hawthorne, S. and Gallagher, S. (2008). Effects of glycyrrhetinic acid and liquorice extract on cell proliferation and prostate-specific antigen secretion in LNCaP prostate cancer cells. Journal of Pharmacy and Pharmacology, 60(5):661-666.

He-Long, B. ; Jing, W.; Chun-Ming, L. and Li, L. (2010). Isolation and purification of flavonoids from Ziziphus jujuba by high-speed counter-current chromatography. Journal of the Chinese Chemical Society, 57(5A): 1071-1076.

Isbrucker, R.A. and Burdock, G.A. (2006). Risk and safety assessment on the consumption of licorice root (Glycyrrhiza sp.), its extract and powder as a food ingredient, with emphasis on the pharmacology and toxicology of glycyrrhizin. Regular Toxicol Pharmacol., 46(3): 167-92.

Isil, Y. and Türkan, K. (2015). Anticancer Agents: saponin and tannin. International Journal of Biological Chemistry, 9:332-340.

Joffin, J.N. and Leyral, G. (2006). Microbiologie technique: tome 1 Dictionnaire des techniques. $4^{\text {ème }}$ édition. CRDP d'aquitaine, Paris, 368 p.

Karamac, M.; Kosinska, A. and Amarowicz, R. (2006). Chelating of Fe (II), Zn (II) and $\mathrm{Cu}$ (II) by tannin fractions separated from hazelnuts, walnuts and almonds. Bromatologia Chemia Toksykologiczna, 39:257-260.

Kashiwada, Y. ; Nonaka, G.I.; Nishioka I.; Chang, J.J. and Lee, K.H. (1992). Antitumor agents, 129. Tannins and related compounds as selective cytotoxic agents. Journal of Natural Products, 55(8):1033-1043.

Kelen, M. and Tepe, B. (2008). Chemical composition, antioxidant and antimicrobial properties of the essential oils of three Salvia species from Turkish flora. Bioresource Technology, 99(10):4096-4104.

Laib, I. (2011). Etude des activités antioxydante et antifongique de l'huile essentielle des fleurs sèches de Lavandula officinalis: Application aux moisissures des légumes secs. Nature et Technologie, 7:44-52.

Lu, Y., Foo and L.Y. (2000). Antioxidant and radical scavenging activities of polyphenols from apple pomace. Food Chemistry, 68(1):81-85.

Masuda, T.; Yonemori, S. and Oyama, Y. (1999). Evaluation of the antioxidan activity of environmental plants: Activity of the leaf extracts from seashore plants. Journal of Agricultural and Food Chemistry, 47(4):1749-1754

Meir, S.; Kanner, J.; Akiri, B. and Hadas, S.P. (1995). Determination and involvement of aqueous reducing compound in oxidative defense systems of various senescing leaves. Journal of Agricultural and Food Chemistry, 43(7):1813-1815.

Min, B.R.; Pinchak, W.E.; Merkel, R.; Walker, S.; Tomita, G. and Anderson, R.C (2008). Comparative antimicrobial activity of tannin extracts from perennial plants on mastitis pathogens. Scientific Research and Essay, 3(2):66-73.

Mobosso, T.; Ngoula, S. and Ngueoui, A. (2010). In vitro antimicrobial activity of extracts and compound of some selected medicinal plants from Cameroon. Journal of Ethnopharmacology, 128(2):476-481.
Mosmann, T. (1983). Rapid colorimetric assay for cellular growth and survival: Application to proliferation and cytotoxicity assays. Journal of Immunological Methods, 65(1-2):55-63.

National Committee for Clinical Laboratory Standards (1997). Performance standards for antimicrobial disk susceptibility; approved standard : NCCLS document M2-A6. $6^{\text {th }}$ Edition. vol. 17, Wayne, Pennsylvania 19087, 26 p.

National Committee for Clinical Laboratory Standards (1999). Methods for determining bactericidal activity of antimicrobial agents; approved guideline: NCCLS document M26-A. $9^{\text {th }}$ Edition. vol. 19, Wayne, Pennsylvania 19087, 32 p.

Nepka, C.; Sivridis, E.; Antonoglou,O.; Kortsaris, A. and Georgellis A. (1999). Chemopreventive activity of very low dose dietary tannic acid administration in hepatoma bearing $\mathrm{C} 3 \mathrm{H}$ male mice. Cancer letters, 141(1-2):57-62.

Nourazarian, S.M.; Nourazarian, A.; Majidinia, M. and Roshaniasl, E. (2016). Effect of root extracts of medicinal herb Glycyrrhiza glabra on HSP90 gene expression and apoptosis in the HT-29 colon cancer cell line. Asian Pacific Journal of Cancer Prevention, 16(18):8563-8566.

Okwu, D.E. and Josiah, C. (2006). Evaluation of the chemical composition of two Nigerian medicinal plants. African Journal of Biotechnology, 5(4):357-361.

Oyaizu, M. (1986). Studies on products of browning reactions: Antioxidative activities of browning reaction prepared from glucosamine. Japanese Journal of Nutrition, 44(6):307-315.

Patil, S.M.; Patil, M.B. and Sapkale, G.N. (2009). Antimicrobial activity of Glycyrrhiza glabra Linn roots. International Journal of Chemical Sciences, 7(1):585-591.

Pelt, J.M. (2001). Les nouveaux remèdes naturels. Quand la nature guérit. Fayard, $317 \mathrm{p}$

Petit, A.C. (2011). Toxicité et utilisation de quelle que Fabacées alimentaire et médicinales. Thèse de doctorat d'état de docteur en pharmacie, université Henri Poincaré, Nancy.

Pizzi, A. (2008). Tannins: Major sources, properties and applications. in monomers, polymers and composites from renewable resources, Belgacem, M.N., Galdini, A., (Eds.). Elsevier, London, UK., pp. 179-199.

Punit R. Bhatt; Kajal B. Pandya; Urvesh D. Patel; Chirag M. Modi; Harshad B. Patel and Bhavesh B. Javia (2019). Antidiabetic, antioxidant and antiinflammatory activity of medicinal plants collected from nearby area of Junagadh, Gujarat. Ann. Phytomed., 8(2):75-84.

Rahman, M.S.; Rashid, M.A. (2008). Antimicrobial activity and cytotoxicity of Eclipta prostrata. Oriental Pharmacy and Experimental Medicine, 8(1):47-52.

Rossi, T.; Castelli, M.; Zandomeneghi, G.; Ruberto, A.; Benassi, L. and Magnoni, C. (2003). Selectivity of action of glycyrrhizin derivatives on the growth of MCF-7 and HEP-2. Cells. Anticancer Research, 23(5A):38133818 .

Sakagami, H.; Jiang, Y.; Kusama, K.; Atsumi, T.; Ueha, T.; Toguchi, M.; Iwakura, I.; Satoh, K.; Ito, H.; Hatano, T. and Yoshida, T. (2000). Cytotoxic activity of hydrolyzable tannins against human oraltumor cell lines-a possible mechanism. Phytomedicine, 7(1):39-47.

Santos, V.R.; Gomes, R.T.; Oliveira, R.R.; Cortes, M.E. and Brandão, M.D.G.L (2009). Susceptibility of oral pathogenic microorganisms to aqueous and ethanolic extracts of Stryphnodendron adstringens (barbatimão). International Journal of Dentistry, 8(1):1-5. 
Sevgi Gezici; Didem Koçum; Fatih Yayla; Nazim Sekeroglu and Adnan A. Khan (2020). Screening for in vitro antioxidant activities, polyphenolic contents and neuroprotective potentials of Clinopodium serpyllifolium subsp. Serpyllifolium endemic to Turkey. Ann. Phytomed., 9(1):181-186.

Shimada, T. (2006). Salivary proteins as a defense against dietary tannins, Journal of Chemical Ecology, 32(6):1149-1163.

Siddhuraju, P. and Becker, K. (2007). The antioxidant and free radical scavenging activities of processed cowpea (Vigna unguiculata L.Walp) seed extracts. Food Chemistry, 101(1):10-19.

Soulef, K.; Abdelouaha, Y. and Dalal, B. (2014). Effect of glycosides extract of the medicinal plant Glycyrrhiza glabra L. from the region of Mlili (southeast of Algeria) on the growth of some human pathogenic bacteria. Journal of Scientific and Innovative Research, 3(1):28-34.

Sun, H.X.; Xie, Y. and Ye, Y.P. (2009). Advances in saponin-based adjuvants Vaccine, 27(12):1787-1796.
Tin, M.M.; Cho, C.H.; Chan, K.; James, A.E. and Ko, J.K. (2007). Astragalus saponins induce growth inhibition and apoptosis in human colon cancer cells and tumor xenograft. Carcinogenesis, 28(6):1347-1355.

Yamina Bouatrous (2019). Antibacterial activity of an essential oil and various extracts of the medicinal plant Thymus hirtus sp algeriensis Boiss. and Reut. Ann. Phytomed., 8(2):108-114.

Yildirim, A.; Mavi, A. and Kara, A., (2001). Determination of antioxidant and antimicrobial activities of Rumex crispus L. extracts, Journal of Agricultural and Food Chemistry, 49(8):4083-4089.

Yokota, T.; Nishio, H.; Kubota, Y. and Mizoguchi, M. (1998). The inhibitory effect of glabridin from liquorice extracts on melanogenesis and inflammation. Pigment Cell Research, 11(6):355-361.

Yokozawa, T.; Cho, E. J.; Rhyu, D. Y.; Shibahara, N. and Aoyagi, K. (2005). Glycyrrhizae radix attenuates peroxynitrite-induced renal oxidative damage through inhibition of protein nitration. Free Radical Research, 39(2):203-211.

Zablotowicz, R.M.; Hoagland, R.E. and Wagner, S.C. (1996). Effect of saponins on the growth and activity of rhizosphere bacteria. In saponins used in food and agriculture. Springer, Boston, MA, pp:83-95.

Kriker Soulef, Y. Bouatrouss, Ramazan Erenler and A. Yahia (2021). Antimicrobial, cytotoxic and antioxidant activity of saponins and tannins extracts of Algerian Glycyrrhiza glabra L. Ann. Phytomed., 10(2):318-326. http:// dx.doi.org/10.21276/ap.2021.10.2.43 